\title{
USING A MARKET-TYPE ALLOCATION SYSTEM TO CONFRONT WATER SCARCITY: AN INTER-DISTRICT APPROACH IN GREECE
}

\author{
LATINOPOULOS D. ${ }^{1,{ }^{*} \text {, }}$ \\ MYLOPOULOS N. ${ }^{2}$ \\ FAFOUTIS C. ${ }^{2}$
}

\author{
${ }^{1}$ Department of Spatial Planning and Development \\ Aristotle University of Thessaloniki \\ GR-54124, Thessaloniki, Greece \\ ${ }^{2}$ Department of Civil Engineering \\ University of Thessaly, GR-38334, Volos, Greece
}

Received: 19/01/14

Accepted: 15/07/14

Available online: $23 / 07 / 2014$ *to whom all correspondence should be addressed e-mail: dlatinop@plandevel.auth.gr

\begin{abstract}
This study examines the implication of a market-based system to allocate water regionally in one of the most intensively irrigated areas of Greece. The proposed approach combines elements from administrative allocation and tradable water rights in order to assess several water supply scenarios under growing water scarcity conditions. In this framework, irrigation water demand functions were derived by means of an optimization model that maximizes the expected annual net benefits from water use in agriculture. Then, an inter-district water market model is developed to compute the most effective water allocation at the basin-level. An institutional reform is suggested, that is linked with the creation of effective water users' associations. The aim of this reform is to achieve a functioning and low-cost trading system at the basin level. The results show that significant volumes of water would be traded under various deficit scenarios, mainly due to the spatial heterogeneity in water use and availability.
\end{abstract}

Keywords: regional water allocation; collective decision making; water demand optimization; water trading; water users' associations

\section{Introduction}

Sustainable and efficient use of water resources in the agricultural sector is an issue of increasing importance, as well as a subject of growing debate. Increasing demands coupled with decreasing resources will inevitably result to severe future water shortages. For this reason, irrigation water has to be managed in a way that ensures efficiency among users and future sustainability. In this context, the European water policy during the past years has changed in orientation, forsaking the pursuit of an increasing supply and turned to the demand side of water management in all water uses, and particularly in agriculture. Such demand policies consist, among others, in water pricing, re-allocation of water resources and introduction of water markets (Latinopoulos, 2008). Specifically, according to the Water Framework Directive (European Commission, 2000; WATECO, 2002), water pricing may provide the right incentives for water use efficiency and sustainable water management, while water users should bear all the costs of water provision (principle of full cost recovery - Article 9 of WFD). In this context, agriculture should adequately contribute to the recovery of the costs of water services, including financial, environmental and resource (or opportunity) costs. 
However, while the implementation of water pricing policies does not pose substantial problems in other water uses (e.g. urban, industrial, hydro-electric use), it has become a highly controversial issue when it comes to agricultural users, especially in the case of Mediterranean countries (OECD, 2001; Iglesias and Blanco, 2008). Social acceptability, environmental effectiveness and political feasibility are some of the main concerns of irrigation water pricing in those countries. Under this perspective, recent economic literature suggests that other policy options, such as allocation mechanisms using water markets (e.g. tradable water permits), could be more effective in ensuring sustainable and efficient water use (Cornish et al. 2004; Latinopoulos and Sartzetakis, 2011). These options are often considered as the most appropriate measures to cope with problems related to water depletion and degradation, as well as to deal with cases where future benefits are heavily discounted (Griffin, 2006).

On the other hand, according to prior experience, water markets seem to operate effectively at the local level but are quite difficult to realize on a regional scale (Keenan et al., 1999) due to several reasons, such as higher level of complexity, hydrological limitations, higher transaction costs, etc. Consequently, regional water markets are still a matter of debate, as some argue that what is most needed for determining the allocation of scarce water supplies in the future are reforms in regional planning and governance (Getches, 1993). A compromise solution could be to trade water rights through farmermanaged associations, which are better known as Water User Associations (WUAs). A WUA is a decentralized and non-governmental association of farmers, located within a specific geographic area that directly engages its members in collective decision-making processes. Hence, effective WUAs ${ }^{1}$ can, among others, implement trades beyond the local (district) scale and provide, at the same time, all the necessary information regarding who wants to buy or sell water (Easter, 1996). In our case, WUAs could act as non-profit organizations that will make (water market) decisions through various forms of participatory local governance.

In this framework, a hybrid approach is designed and simulated - combining elements from administrative allocation and tradable water permits - in an intensively irrigated area, where water is currently treated as a free-access resource. Hence, annual water transactions between various districts are examined for different future water supply scenarios. The assumption here is that irrigators coming from those districts should form financial autonomous WUAs in order to plan and control water allocation, as well as, in order to trade water-rights among districts. WUAs are thus supposed to react as rational water managers, who are also well informed about water practices and economic results at the individual farm level. Gains from water trading are presumed to increase as water scarcity increases (Zilberman and Schoengold, 2005), as well as when significant variation is present at agricultural activities, production functions and irrigation techniques. Part of these revenues may also help to fund improvements and maintenance in the water system (Easter and Hearne, 1995).

Non-linear mathematical programming models and econometric analysis were both employed in order to estimate the demand functions for irrigation water in all districts in the study area. An inter-district transfer model was then applied, according to which, water transfers can occur between WUAs in the same basin (Karla Basin, Greece).

\section{Study area description}

The watershed of Lake Karla is located in the eastern part of Thessaly in central Greece. The watershed is surrounded by Mount Kisavos to the northeast, the Mavrovouni Mountain to the east and south, and Pinios River to the northwest. The natural basin of Karla had a total extent of $1,663 \mathrm{~km}^{2}$ but after the construction of complimentary works, the drainage area of the restored lake Karla will be $1,171 \mathrm{~km}^{2}$ (Loukas et al., 2008). Karla's aquifer area is about $500 \mathrm{~km}^{2}$ (Figure 1).

\footnotetext{
${ }^{1}$ Successful examples of WUA systems are reported in many countries, such as USA, India, Mexico, South Korea, Nepal, Pakistan, Italy, Spain and Turkey (Hamdy and Lacirignola, 1997; Çakmak et al. 2004; Albiac et al., 2007). These examples show significant improvements in irrigation services, environmental impacts and financial performance.
} 
Most of the study area is plain with an altitude from 45 to $65 \mathrm{~m}$. Only to the southwest the altitude reaches up to $90 \mathrm{~m}$. Thessaly plain is traversed by Pinios River and its waters are used primarily for irrigation. However, the overexploitation of the groundwater system has led to the deterioration of the already disturbed water balance and the degradation of water resources. Over the years, various locations within Pinios river basin have been proposed for the creation of reservoirs, but up until now only a dam (in Smokovo) has been constructed. Apart from this, only small scale surface water developments took place in the broader area (e.g. small reservoirs and lagoons).

Lake Karla basin is an intensely cultivated agricultural region. The intense and extensive cultivation of water demanding crops, such as cotton, has led to a remarkable water demand increase during the last decades, which is constantly resulting to over-exploitation of groundwater resources. Besides, under the existing water demand management strategy, water deficits were estimated for about half of the years for the historical period 1960-2002. With water being so scarce, there is a great pressure for better management of water resources. However, according to Loukas et al., (2007), the best policy aiming at a non-deficient water balance of Karla River Basin is the application of water demand strategies, since water supply strategies would have limited effectiveness. Panagopoulos et al., (2013) took a step forward by developing and applying a decision support tool aiming to suggest the optimal use of various best management practices (BMPs) ${ }^{2}$ in the Pinios River Basin. According to their results, various BMPs along with a tiered water pricing system would form a sustainable action plan against the desertification of the study area.

The purpose of this study is to propose an alternative water (demand) management strategy by investigating the potential effects of a tradable water rights system, which is theoretically more effective than water pricing as a means of achieving allocation efficiency. It should be noted that the present work focuses on the irrigated agriculture of four neighboring municipalities: Karla, Feres, Armenio and Kileler $^{3}$. It is also worth-noting that the administrative boundaries were used to arbitrarily divide the study area to potential irrigation districts, taking into consideration that people living in the same communities are more likely to cooperate themselves.

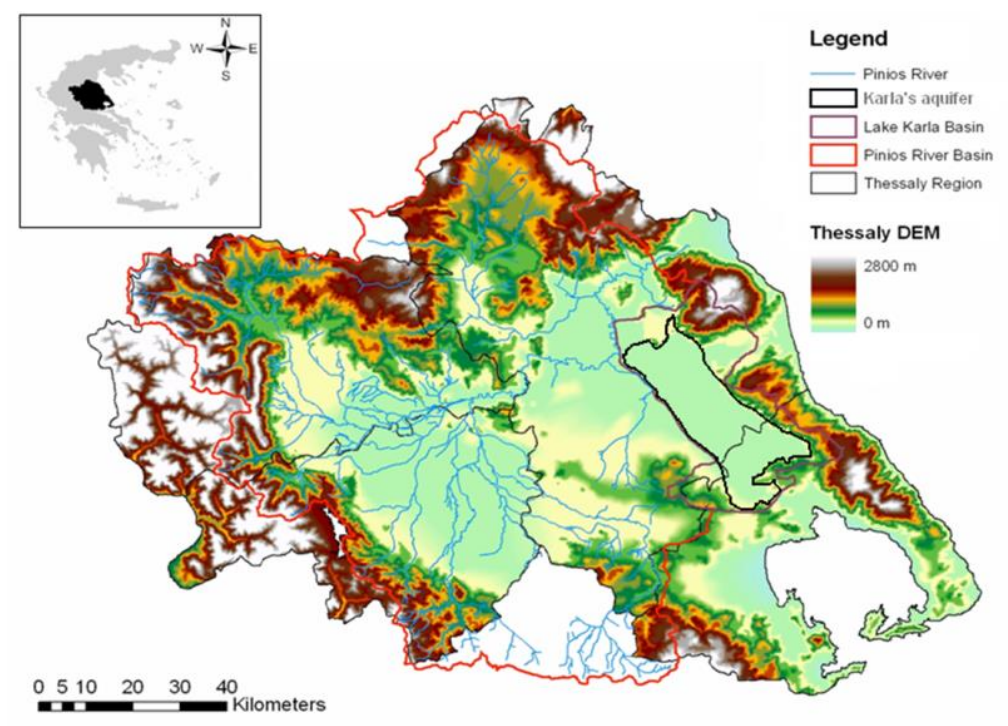

Figure 1. Map of the Region of Thessaly indicating the Lake Karla Basin

\footnotetext{
${ }^{2}$ A variety of high and low-tech irrigation BMPs were examined under the current and a volumetric pricing scenario by Panagopoulos et al (2013), including deficit irrigation, precision agriculture, conveyance efficiency improvement and wastewater reuse.

${ }^{3}$ In order to achieve more accurate results and to increase flexibility in water transactions, we brought the unit of analysis for the municipalities of Armenio and Kileler down to the level of municipal departments, resulting thus to a total of 10 districts.
} 


\subsection{Water administration in the study area}

In the current water management regime, two Local Land Improvement Boards ${ }^{4}$ (TOEV Piniou and TOEV Karlas) manage water allocation, collect farmers' fees and manage collective activities. TOEVs, are actually water user organizations that have the legal status of public organizations, while their members are private agents (irrigators/property owners who benefit from the services provided by the organization). Institutional and legal deficiencies, as well as limited stakeholder participation in water management, are the key elements explaining the current inefficient water allocation and low investments (improvements) on irrigation networks ${ }^{5}$.

As stated by Munaretto (2003), public-private collaboration is crucial to achieve high levels of irrigation efficiency in the study area but undermined by lack of trust on public agencies, which fail to enforce the law and to provide technical and financial support to farmers. In order to fill this gap, local farmers are often united in groups and cooperatives. This is quite reasonable behavior since, as several studies have reported, there is a high correlation between farmers' participation in the management of irrigation systems and their performance and sustainability (Hamdy and Lacirignola, 1997). Public participation has also become highly important in the implementation of the European WFD ${ }^{6}$. In this context, the present study recommends that local farmers' cooperatives should attempt to establish larger and formal institutions, such as WUAs, in each irrigation district. These institutions should follow the Spanish model where the communities of irrigators are able to administer the resources and infrastructures, to share water among farmers and to have a major role in water management at the district level (Berbel et al., 2007).

Usually, a WUA lies somewhere in between a market system and a public administration system, providing a more flexible mechanism, since the rules of allocation and pricing are set by the users themselves (Dudu and Chumi, 2008). According to Easter and Liu (2007), there is a strong relationship between willingness to pay for water services and farmers' participation through local WUA, in the entire irrigation management process. In other words, farmers are more likely to pay for water if they are involved in a decision-making process concerning the regulation of water consumption/supply and water transfers among farmers and/or irrigation districts. Furthermore, a WUA will provide the public participation mechanism that may improve decision-making (public acceptance, commitment and support with regard to the decision making process), by ensuring that decisions about water pricing and water allocation will be influenced by the views and experience of those affected by them (WFD public participation working group, 2002). Less litigation and more effective implementation of water allocation decisions are also some potential benefits that can result from the proposed participatory approach.

It is worthwhile to mention that the aforementioned methodology requires an institutional change that will allow the operation of water transactions and that will develop new participatory approaches to water resources management (i.e. through the establishment of local WUAs ${ }^{7}$ ). Since the magnitude of net benefits from institutional changes in the water sector is a direct function of the degree of water

\footnotetext{
${ }^{4}$ Also known as TOEVs from the Greek acronym

${ }^{5}$ For example, the fees collected by local TOEVs cover only part of the maintenance, operation and administration costs, while the rest is covered by the State.

${ }^{6}$ Namely, WFD is the first directive that explicitly combines environmental goals with public participation (Kastens and Newig, 2008). Article 14 of the WFD describes the three main forms of public participation: (a) active involvement, (b) consultation in the planning process and $(c)$ information supply. The participatory aspect was further covered in the guidance document on public participation (WFD public participation working group, 2002). According to the guidance document, public participation should include, among others, the consultation of water users' representatives (e.g. WUAs). Herein, consultation will be necessary in order to derive the water demand function per district, as well as in order to design the transaction mechanisms. Sufficient information about water pricing and allocation will be also provided by the representatives (WUAs) to all key stakeholders (farmers) in order to enable their active involvement.

${ }^{7}$ A full joint management mechanism should be established, according to which the WUA would be responsible for: (a) the operation and maintenance of irrigation systems, (b) the farmers' representation and (c) the ownership of irrigation systems (i.e. the ownership of water rights), while the public (River Basin) agency would have a regulatory role.
} 
scarcity (Saleth and Dinar, 1999), the economic incentives for the proposed institutional change are expected to increase with increasing water scarcity.

\section{Methodology}

Up to now, irrigation water in the study area is considered as a free access resource and no market mechanism is in place to trade water. Financial constraints and current public perception of water as a common good pose a risk on implementing tradable permits at the farm level. Therefore, potential water shortages in each district will be first addressed by means of a reallocation - at the district level of irrigation water to the most efficient uses (crops). The basic assumption here is that water allocation is flexible within each district and that collective decision making would be feasible under the supervision of a local participatory organization (WUA). In this framework, mathematical (non-linear) programming may be used in order to maximize economic benefits and estimate an average water demand function, at the district level, for various water deficit scenarios.

At the larger scale (Lake Karla Basin), however, it is difficult to establish an efficient participatory organization structure for collective decision-making. Nevertheless, at this scale it is quite likely that under the supervision of the basin agency - individual institutions (WUAs) will cooperate, aiming to increase their economic surpluses through water trades. For this reason, the potential outcome of an administrative-based allocation that enables temporary (annual) water trading among districts is further examined. This market system will be actually simulated from a social planner's perspective, trying to maximize aggregate economic benefits (in Karla Basin) under various water deficit scenarios. In other words, following the general approach of Qureshi et al. (2009), each district is treated as though it were a decision maker attempting to maximize economic returns from producing irrigated crops, releasing land for dry-land activity and/or selling water on temporary inter-district water markets.

\subsection{Derivation of water demand functions}

The first step in this analysis is to derive the demand functions for irrigation water at the district level. Within this framework, a water demand optimization model is used to maximize the expected annual net benefits from water use for each district. Each district is treated as a single unit; where decisionmakers are attempting to maximize the net benefits from producing irrigated and non-irrigated crops, subject to a number of water, land and agronomic constraints. Gross margin functions (i.e. aggregate revenues minus variable input and water supply costs) are used to approximate agricultural net benefits.

As noted by Ortega et al. (2004), any attempt to optimize irrigation water use must first analyze the relationship between crops' water requirements and crop yields, and then to analyze different water deficit strategies. For this reason, a non-linear optimization technique, developed by Latinopoulos (2005) for the farm level analysis was modified and used herein for farmers' representatives at the district level. This technique consists of three interrelated steps: (a) the analysis of water effect on the productivity of each crop (water-yield relationships), (b) the derivation of gross margin functions for all crops in the reference areas and for various irrigation depths (water availability levels), and (c) the estimation of a water demand function for each district.

The water-yield relationships for all the crops in the study area were estimated according to the Doorenbos and Kassam's (1979) crop-water response function, where, for computational reasons all the potential water reductions were equally apportioned over the whole irrigation period (year). Average crop-water yield functions in each district (i.e. the crop water function of a representative farmer) were assumed to follow a concave curve, which is a common shape for empirical water production functions:

$\mathrm{Y}_{\mathrm{w}_{\mathrm{k}, \mathrm{i}}}=\alpha_{0}+\alpha_{1 i, k} \mathrm{w}_{\mathrm{i}, \mathrm{k}}-\alpha_{2 i, \mathrm{k}} \mathrm{w}_{\mathrm{i}, \mathrm{k}}^{2}$

where, $Y_{w}$ is the average crop water productivity $\left(\mathrm{kg} \mathrm{ha}^{-1}\right)$ for crop $k$ in district $i$, for a given level of water availability, $\mathrm{w}_{\mathrm{i}, \mathrm{k}}\left(\mathrm{m}^{3} \mathrm{ha}^{-1}\right)$. The coefficients $\alpha_{0}, \alpha_{1}, \alpha_{2}$ are econometrically estimated parameters connecting (simulated) crop responses to a set of sequential water consumption reductions. Crop 
responses were, in turn, estimated according to actual data concerning local climate, irrigation methods and crop characteristics, and considering that all the other inputs are constant. This procedure is performed by means of a computer software program, CROPWAT, which is provided by FAO (Smith, 1992). Aggregate gross margin functions (in $€ /$ year), $\mathrm{GM}_{\mathrm{i}}$, are then derived for each district by the following expression:

$\mathrm{GM}_{\mathrm{i}}=\sum_{\mathrm{k}} \mathrm{m}_{\mathrm{k}, \mathrm{i}} \mathrm{Y}_{\mathrm{w}_{\mathrm{k}, \mathrm{i}}} \mathrm{p}_{\mathrm{k}}-\mathrm{C}_{\mathrm{k}, \mathrm{i}}$

where $m_{k, i}$ is the area in district i cultivated with crop $k(h a), p_{k}$ is the commercial price of the agricultural product $(€ / \mathrm{kg})$ and $C_{k, i}$ are the average variable costs of production $(€)$, including water application costs (details on these data are provided in Tables 1 and 2). According to Eq.1 and Eq.2a, all the GM functions may be represented by a second order polynomial function of $\mathrm{w}_{\mathrm{i}, \mathrm{k}}$. In the next step, local agricultural decision-making is supposed to maximize the above benefit functions (Eq. 2a) under a set of land and water availability constraints:

$$
\begin{array}{ll}
\sum_{k} m_{k, i} \leq M_{i} & \text { (Total land constraint) } \\
m_{k, i} \leq m_{M A, i}, m_{k, i} \geq m_{m A, i} & \text { (Individual crop land constraints) } \\
\sum_{k} w_{k, i} m_{k, i} \leq W_{i} & \text { (Total water constraint) }
\end{array}
$$

where $M_{i}$ is district's i agricultural area, $W_{i}$ is the amount of irrigation water that is actually used in each district, while $m_{M A, i}$ and $m_{m A, i}$ represent the maximum and minimum areas allowed to individual crops according to the actual cropping patterns, the agricultural policy and the marketing channels in the study area (Latinopoulos, 2008). To solve the above maximization problem we developed a constrained optimization (quadratic programming) model in each district using the LINGO software (Schrage, 1999).

In order to estimate the water demand function in each district, the above maximization model was run for different values of $W_{i}$. Hence, several scenarios were formulated, representing different levels (percentage) of water cuts $\left(\mathrm{g}_{\mathrm{i}}: 0<\mathrm{g}_{\mathrm{i}} \leq 1\right)$, with regard to the actual (optimum) water use in the area $\left(\mathrm{W}_{\mathrm{i}}\right)^{8}$. A dual variable associated with the water constraint $(\lambda)$ - for different levels of water availability - can be used in order to denote the shadow price of irrigation water (Garrido, 2000). Its value is a function $\lambda(\cdot)$ of water availability $\left(g_{i} W_{i}\right)$, as well as of local farming parameters $\left(Z_{i}\right)$. Thus, the economic surplus of district $i(D S)$ can be approximated by calculating the area under the function $\lambda\left(g_{i} W_{i}, Z_{i}\right)$ :

$$
\mathrm{DS}_{\mathrm{i}}=\int_{0}^{\mathrm{g}_{\mathrm{i}} \mathrm{w}_{\mathrm{i}}} \lambda_{\mathrm{l}}\left(\mathrm{w}, \mathrm{Z}_{\mathrm{i}}\right)
$$

The pairs $\left(\mathrm{g}_{\mathrm{i}} \mathrm{W}_{\mathrm{i}}, \lambda_{\mathrm{l}}\right)$ from the above surplus functions can be econometrically estimated and then used in order to fit a continuous (semi-logarithmic) demand function in each district (Garrido, 2000).

\subsection{Inter-district water market model}

The overall objective of the aforementioned institutional scenario is to maximize aggregated economic benefits in the study area through water trading. Hence, WUAs that are interested in purchasing additional volumes of water would buy these volumes (i.e. water rights) from districts that are willing to sale water quantities at a price higher than their current shadow price of water. It should be also noted that due to the administrative based water market system, it is assumed that there are no significant

\footnotetext{
${ }^{8}$ It should be noted that irrigation use efficiency under water constraints can be improved by means of deficit irrigation, as well as, by withdrawing irrigation and leaving land for dry-land production
} 
transaction costs between buyers and sellers. On this account the inter-district model that was initially introduced by Garrido (2000) was modified as follows ${ }^{9}$ :

$\max _{b_{i}, p_{m}} T S=\sum_{i} D S_{i}\left(g_{i} W_{i}+b_{i}, p_{m}\right)$

where TS is the total surplus from agriculture ( $€$ /year) in the study area (algebraic summation of all DSs), $b_{i}$ is the amount $\left(m^{3}\right.$ year $\left.{ }^{-1}\right)$ of water traded $\left(b_{i}>0\right.$ : water is purchased, $b_{i}<0$ : water is sold $)$ and $p_{m}$ is the market price of water-rights $\left(€ / \mathrm{m}^{3}\right)$, as resulted through the maximization problem.

Equation 4 is then subject to the following four constraints:

(1) Water availability constraint in each district (future water use in a district should not exceed the actual current use):

$g_{i} \cdot W_{i}+b_{i} \leq W_{i}$

There are two possible ways to structure the water allocation system (i.e. to decide about the water cuts, $\mathrm{g}_{\mathrm{i}}$, in each district). The first is based on the proportional doctrine where all future scenarios should follow equal (proportional) annual reductions $\left(g_{1}=g_{2}=\ldots g_{10}\right)$ in water consumption. The second one is based on priority rights, where custom priorities are recognized for various reasons (political, economical, social, environmental, etc.), so that different values of $\mathrm{g}_{\mathrm{i}}$ are chosen for each district.

(2) Aggregate water demand (purchases) and aggregate water supply (sales) should be equal in all allocation scenarios:

$\sum_{i} b_{i} \cdot L_{i}=0$

where, $L_{i}$ is the weighting coefficient adjusting the agricultural area of each district within the study area.

(3) Water markets should make all districts (WUAs) at least equally well-off as compared to the nonmarket scenario (i.e. situation where water exchanges between districts are not permitted). In other words, as stated by Garrido (2000), any solution to this model $\left(b_{i}, p_{m}\right)$ would be Pareto-superior to the no-trade scenario $(0,0)$ :

$D S_{i}\left(g_{i} W_{i}+b_{i}, p_{m}\right) \geq D S_{i}\left(g_{i} W_{i}\right)$

(4) All water sellers, in order to gain from water transactions should guarantee a market price (equilibrium price) higher than the shadow price of water at their district (i.e. higher than the opportunity cost of water):

$p_{m} \geq \lambda_{l}\left(g_{i} W_{i}\right), \forall i: b_{i}<0$

It should be noted that an equivalent price constraint for water buyers was found to be redundant (i.e. the current model formation and the selected constraints secure that water buyers will pay up to their shadow price). The optimization software LINGO was used once again to solve the water market model and yield the optimal solutions. Namely, quadratic programming models were used to maximize Eq.4 subject to the four sets of constraints (i.e. Eq.5-8).

\footnotetext{
${ }^{9}$ Garrido (2000) uses three models: (a) a farm model where each individual farmer (irrigator) maximizes its profit function (i.e. derivation of individual water demand functions), (b) an intra-district water market model developed to simulate water transactions by individual farmers in each irrigation district and (c) an inter-district water market model to analyze potential water exchanges between irrigation districts. In this study the first model is modified for the case of the representative farmer in each district (i.e. profit functions and constraints are formulated at the district level), while the second model is omitted because transactions can only be executed at the district level (i.e. among WUAs).
} 
Table 1. Current crop mix in the districts of the study area

\begin{tabular}{|c|c|c|c|c|c|c|c|c|c|c|c|c|}
\hline \multirow[b]{2}{*}{ Districts } & \multicolumn{12}{|c|}{ Cultivated area (ha) } \\
\hline & cotton & sugar beets & alfalfa & corn & $\begin{array}{l}\text { apple } \\
\text { trees }\end{array}$ & vine & tomato & melons & wheat & $\begin{array}{c}\text { Other } \\
\text { vegetables }\end{array}$ & Nut trees & Olive trees \\
\hline $\begin{array}{l}\text { Karla } \\
\text { (D1) }\end{array}$ & $\begin{array}{l}3,249.0 \\
(51.0 \%)\end{array}$ & - & $\begin{array}{c}71.3 \\
(1.1 \%)\end{array}$ & $\begin{array}{c}98.6 \\
(1.5 \%)\end{array}$ & - & - & $\begin{array}{c}93.9 \\
(1.5 \%)\end{array}$ & - & $\begin{array}{l}1,804.7 \\
(28.3 \%)\end{array}$ & - & $\begin{array}{l}1,052.8 \\
(16.5 \%)\end{array}$ & - \\
\hline $\begin{array}{c}\text { Feres } \\
\text { (D2) }\end{array}$ & $\begin{array}{c}832.2 \\
(53.5 \%)\end{array}$ & - & $\begin{array}{c}16.3 \\
(1.0 \%)\end{array}$ & $\begin{array}{c}34.8 \\
(2.2 \%)\end{array}$ & - & - & $\begin{array}{c}32.2 \\
(2.1 \%)\end{array}$ & - & $\begin{array}{c}635.3 \\
(40.7 \%)\end{array}$ & - & $\begin{array}{c}7.8 \\
(0.5 \%)\end{array}$ & - \\
\hline $\begin{array}{l}\text { Armenio } \\
\text { (D3) }\end{array}$ & $\begin{array}{l}1,386.0 \\
(76.0 \%)\end{array}$ & $\begin{array}{c}41.0 \\
(2.2 \%)\end{array}$ & - & $\begin{array}{c}84.0 \\
(4.6 \%)\end{array}$ & - & - & - & - & $\begin{array}{c}313.0 \\
(17.2 \%)\end{array}$ & - & - & - \\
\hline $\begin{array}{l}\text { M.Monastirio } \\
\text { (D4) }\end{array}$ & $\begin{array}{c}447.0 \\
(34.8 \%)\end{array}$ & $\begin{array}{c}2.0 \\
(0.2 \%)\end{array}$ & $\begin{array}{c}15.0 \\
(1.2 \%)\end{array}$ & $\begin{array}{c}65.0 \\
(5.1 \%)\end{array}$ & $\begin{array}{c}71.5 \\
(5.6 \%)\end{array}$ & $\begin{array}{c}3.5 \\
(0.3 \%)\end{array}$ & - & $\begin{array}{c}3.0 \\
(0.2 \%)\end{array}$ & $\begin{array}{c}676.0 \\
(52.7 \%)\end{array}$ & - & - & - \\
\hline $\begin{array}{l}\mathrm{Niki} \\
\text { (D5) }\end{array}$ & $\begin{array}{l}1,872.0 \\
(81.4 \%)\end{array}$ & $\begin{array}{c}86.0 \\
(3.7 \%)\end{array}$ & $\begin{array}{c}5.0 \\
(0.2 \%)\end{array}$ & $\begin{array}{c}42.5 \\
(1.8 \%)\end{array}$ & - & - & - & - & $\begin{array}{c}293.0 \\
(12.7 \%)\end{array}$ & - & - & - \\
\hline $\begin{array}{l}\text { Sotirio } \\
\text { (D6) }\end{array}$ & $\begin{array}{l}1,535.0 \\
(76.7 \%)\end{array}$ & $\begin{array}{c}53.0 \\
(2.6 \%)\end{array}$ & $\begin{array}{c}5.0 \\
(0.2 \%)\end{array}$ & $\begin{array}{c}52.0 \\
(2.6 \%)\end{array}$ & $\begin{array}{c}9.0 \\
(0.4 \%)\end{array}$ & - & - & $\begin{array}{c}2.0 \\
(0.1 \%)\end{array}$ & $\begin{array}{c}344.5 \\
(17.2 \%)\end{array}$ & - & - & - \\
\hline $\begin{array}{l}\text { Agnanteri } \\
\text { (D7) }\end{array}$ & $\begin{array}{l}5,491.0 \\
(67.5 \%)\end{array}$ & $\begin{array}{c}30.0 \\
(3.7 \%)\end{array}$ & - & $\begin{array}{c}14.5 \\
(1.8 \%)\end{array}$ & - & - & - & - & $\begin{array}{c}200.0 \\
(24.6 \%)\end{array}$ & - & - & $\begin{array}{c}20.0 \\
(2.5 \%)\end{array}$ \\
\hline $\begin{array}{l}\text { Kalamaki } \\
\text { (D8) }\end{array}$ & $\begin{array}{l}1,030.0 \\
(65.0 \%)\end{array}$ & $\begin{array}{c}95.0 \\
(6.0 \%)\end{array}$ & $\begin{array}{c}20.0 \\
(1.3 \%)\end{array}$ & $\begin{array}{c}98.0 \\
(6.2 \%)\end{array}$ & - & $\begin{array}{c}0.7 \\
(0.04 \%)\end{array}$ & - & - & $\begin{array}{c}25.0 \\
(1.6 \%)\end{array}$ & $\begin{array}{c}0.7 \\
(0.04 \%)\end{array}$ & - & $\begin{array}{c}315.0 \\
(19.9 \%)\end{array}$ \\
\hline $\begin{array}{l}\text { Kileler } \\
\text { (D9) }\end{array}$ & $\begin{array}{l}1,840.0 \\
(94.8 \%)\end{array}$ & $\begin{array}{c}9.5 \\
(0.5 \%)\end{array}$ & $\begin{array}{c}22.0 \\
(1.1 \%)\end{array}$ & $\begin{array}{c}19.5 \\
(1.0 \%)\end{array}$ & - & - & - & - & $\begin{array}{c}50.0 \\
(2.6 \%)\end{array}$ & - & - & - \\
\hline $\begin{array}{l}\text { Melissa } \\
\text { (D10) }\end{array}$ & $\begin{array}{l}1,050.0 \\
(89.4 \%)\end{array}$ & $\begin{array}{c}40.0 \\
(3.4 \%)\end{array}$ & - & $\begin{array}{c}28.0 \\
(2.4 \%)\end{array}$ & - & $\begin{array}{c}1.5 \\
(0.1 \%)\end{array}$ & - & - & $\begin{array}{c}50.0 \\
(4.3 \%)\end{array}$ & $\begin{array}{c}5.0 \\
(0.4 \%)\end{array}$ & - & - \\
\hline
\end{tabular}

Source: Raw data from the Directorate of Agricultural Development, Region of Thessaly 
Table 2. Crop prices and variable costs of production for irrigated and non-irrigated crops in the study area

\begin{tabular}{cccccc}
\hline Irrigated Crops & $\begin{array}{c}\text { Crop prices } \\
(\boldsymbol{\epsilon} / \mathbf{k g r})\end{array}$ & $\begin{array}{c}\text { Production } \\
\text { costs }(\boldsymbol{\epsilon} / \mathrm{ha})\end{array}$ & $\begin{array}{c}\text { Non irrigated } \\
\text { crops }\end{array}$ & $\begin{array}{c}\text { Crop prices } \\
(\boldsymbol{\epsilon} / \mathbf{k g r})\end{array}$ & $\begin{array}{c}\text { Production } \\
\text { costs }(\boldsymbol{\epsilon} / \mathrm{ha})\end{array}$ \\
\hline Cotton & 0.47 & 797 & Cotton & 0.47 & 416 \\
\hline Sugar-beets & 0.04 & 975 & Lentils & 0.88 & 907 \\
\hline Alfalfa & 0.15 & 356 & Alfalfa & 0.15 & 150 \\
\hline Corn & 0.14 & 933 & Barley & 0.15 & 218 \\
\hline Apple trees & 0.53 & 3,440 & Pees & 0.25 & 446 \\
\hline Vines & 0.36 & 2,260 & Vines & 0.33 & 990 \\
\hline Tomato & 0.26 & 2,770 & Melons & 0.16 & 571 \\
\hline Watermelons & 0.07 & 1,210 & Wheat & 0.13 & 258 \\
\hline $\begin{array}{c}\text { Other } \\
\text { vegetables }\end{array}$ & 0.62 & 1,510 & Nut trees & 2.64 & 290 \\
\hline Nut trees & 2.64 & 801 & Olive trees & 2.35 & 240 \\
\hline Olive trees & 2.35 & 547 & & & \\
\hline
\end{tabular}

Source: Raw data from the Directorate of Agricultural Development, Region of Thessaly

\section{Water allocation results}

This section presents the allocation solutions as resulted from a set of alternative water supply scenarios. For this reason, the water demand functions are first estimated for the farmers' representative (WUA) in each district. Table 3 shows: (a) the current water use, (b) the net agricultural income (aggregate gross margin) and (c) the water demand function in each district, derived from the above mentioned procedure (Eq.1-Eq.3). According to this table, higher water consumption $\left(\mathrm{m}^{3}\right.$ per district) is observed in the municipality of Karla (D1), mainly due to its large agricultural area. On the other hand, higher consumption per hectare (water use intensity $-\mathrm{m}^{3}$ ha $\mathrm{a}^{-1}$ ) is currently found in Kalamaki (D8), Kileler (D9) and Melissa (D10) districts, where cotton is the dominant crop. Kalamaki and Karla districts are also found to be associated with higher net income from agriculture activity (in $€ / h a$ ). Water demand functions were econometrically derived by means of a semi-logarithmic (linear-log) function using the pairs of points $\left(g_{i} W_{i}, \lambda\right)$ :

$S P_{i}=\gamma_{i}+\delta_{i} \cdot \operatorname{Ln}\left(g_{i} W_{i}\right)$

where, $\mathrm{SP}_{\mathrm{i}}$ is the shadow (marginal) price of water and $\gamma, \delta$ are specific for each district (WUA). Hence, for different levels of water constraints $\left(\mathrm{g}_{\mathrm{i}}\right)$ it is possible to estimate the marginal (shadow) value of irrigation water in each district. It should be also mentioned that for the selected linear-log model (Eq. 9), the elasticity of demand is equal to $\delta_{\mathrm{i}} / \mathrm{SP}_{\mathrm{i}}$.

Concerning the potential future allocation scenarios of irrigation water (i.e. the values of $g_{i}$ ), the following hypothetical water deficit scenarios where examined:

Scenario 1: $20 \%$ reduction in water availability to all districts ( $\mathrm{g}_{\mathrm{i}}=0.8 \forall i: i=1, . ., 10$ )

Scenario 2: $40 \%$ reduction in water availability to all districts ( $\mathrm{g}_{\mathrm{i}}=0.6 \forall i: i=1, . ., 10$ )

Scenario 3: $50 \%$ reduction in water availability to all districts ( $\mathrm{g}_{\mathrm{i}}=0.5 \forall i: i=1, \ldots, 10$ )

Scenario 4: $50 \%$ limited water availability in eastern districts $\left(g_{1}, g_{2}=0.5 ; g_{3, .,}, g_{10}=1.0\right)$

Scenario 5: $50 \%$ limited water availability in western districts $\left(g_{1}, g_{2}=1.0 ; g_{3, . .,} g_{10}=0.5\right)$ 
Table 3. Current water use, net income and regional demand functions

\begin{tabular}{|c|c|c|c|c|c|}
\hline \multirow{2}{*}{ Districts } & \multicolumn{2}{|c|}{ Water use } & \multicolumn{2}{|c|}{ Net income } & \multirow{2}{*}{$\frac{\text { Water demand functions }}{{\text { (Per hectare })^{1}}^{1}}$} \\
\hline & $10^{3} \mathrm{~m}^{3}$ & $\mathrm{~m}^{3} / \mathrm{ha}$ & $10^{3} €$ & $€ /$ ha & \\
\hline Karla (D1) & $42,740.8$ & 6709 & 7831.4 & 1229.3 & $\mathrm{SP}_{1}=0.3461-0.0373 \mathrm{Ln}\left(\mathrm{g}_{1} \mathrm{~W}_{1}\right)\left[R^{2}=0.97\right]$ \\
\hline Feres (D2) & 9130.5 & 5846 & 655.3 & 419.6 & $\mathrm{SP}_{2}=0.1119-0.0107 \mathrm{Ln}\left(\mathrm{g}_{2} \mathrm{~W}_{2}\right)\left[R^{2}=0.65\right]$ \\
\hline Armenio (D3) & $12,446.0$ & 6823 & 638.0 & 349.8 & $\mathrm{SP}_{3}=0.1742-0.0170 \mathrm{Ln}\left(\mathrm{g}_{3} \mathrm{~W}_{3}\right)\left[R^{2}=0.51\right]$ \\
\hline M.Monastirio (D4) & 7007.4 & 5462 & 978.0 & 762.2 & $\mathrm{SP}_{4}=0.9423-0.1108 \mathrm{Ln}\left(\mathrm{g}_{4} \mathrm{~W}_{4}\right)\left[R^{2}=0.90\right]$ \\
\hline Niki (D5) & $16,145.1$ & 7024 & 816.0 & 355.0 & $\mathrm{SP}_{5}=0.1129-0.0096 \mathrm{Ln}\left(\mathrm{g}_{5} \mathrm{~W}_{5}\right)\left[R^{2}=0.47\right]$ \\
\hline Sotirio (D6) & $13,692.6$ & 6944 & 771.2 & 385.5 & $\mathrm{SP}_{6}=0.1861-0.0182 \mathrm{Ln}\left(\mathrm{g}_{6} \mathrm{~W}_{6}\right)\left[R^{2}=0.62\right]$ \\
\hline Agnanteri (D7) & 5374.0 & 6605 & 461.6 & 567.4 & $\mathrm{SP}_{7}=0.2423-0.0245 \mathrm{Ln}\left(\mathrm{g}_{7} \mathrm{~W}_{7}\right)\left[R^{2}=0.57\right]$ \\
\hline Kalamaki (D8) & $12,734.8$ & 8038 & 2586.0 & 1632.1 & $\mathrm{SP}_{8}=1.807-0.2023 \mathrm{Ln}\left(\mathrm{g}_{8} \mathrm{~W}_{8}\right)\left[R^{2}=0.79\right]$ \\
\hline Kileler (D9) & $14,729.9$ & 7589 & 826.4 & 425.8 & $\mathrm{SP}_{9}=0.2847-0.0279 \operatorname{Ln}\left(\mathrm{g}_{9} \mathrm{~W}_{9}\right)\left[R^{2}=0.69\right]$ \\
\hline Melissa (D10) & 8765.1 & 7462 & 555.9 & 473.3 & $\mathrm{SP}_{10}=0.1963-0.0198 \mathrm{Ln}\left(\mathrm{g}_{10} \mathrm{~W}_{10}\right)\left[R^{2}=0.75\right]$ \\
\hline
\end{tabular}

Note: ${ }^{1}$ The values in brackets show the $\mathrm{R}^{2}$ values of the econometric specification

It should be mentioned that the first three scenarios are based on symmetric water allocation between all districts in the study area. On the contrary, Scenarios 4 and 5 are used to examine the effect of asymmetric allocation, where, absolute priority is given to either western (Scenario 4) or eastern (Scenario 5) districts. Table 4 presents the solutions of the inter-district water allocation model for all the above-described scenarios. Specifically, equilibrium prices and water-right exchanges (in terms of water demand and supply among WUAs) are examined under the assumption of zero transaction costs. Total regional water-rights exchanges, as well as total economic transactions are also depicted in this table.

Table 4. Water allocation results - purchases and sales of water per district

\begin{tabular}{|c|c|c|c|c|c|c|}
\hline \multirow{2}{*}{\multicolumn{2}{|c|}{ Foulihrium pricos $\left(f / m^{3}\right)$}} & Scenario 1 & Scenario 2 & Scenario 3 & Scenario 4 & Scenario 5 \\
\hline & Equilibrium prices $\left(€ / \mathrm{m}^{3}\right)$ & 0.0317 & 0.0398 & 0.0430 & 0.0394 & 0.0385 \\
\hline \multicolumn{2}{|c|}{ Total water exchanges $\left(10^{3} \mathrm{~m}^{3}\right)$} & $\begin{array}{c}3112.9 \\
(2.19 \%)^{*}\end{array}$ & $\begin{array}{c}13,037.0 \\
(9.13 \%) \\
\end{array}$ & $\begin{array}{c}13,047.2 \\
(9.15 \%) \\
\end{array}$ & $\begin{array}{c}11,853.5 \\
(8.30 \%) \\
\end{array}$ & $\begin{array}{l}20,849.3 \\
(14.60 \%)\end{array}$ \\
\hline \multicolumn{2}{|c|}{ Total market value $\left(10^{3} €\right)$} & 98.97 & 518.9 & 561.6 & 467.0 & 802.7 \\
\hline \multirow{10}{*}{ 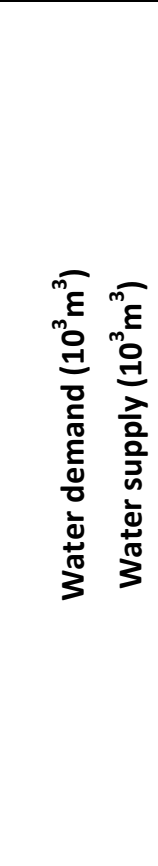 } & Karla (D1) & $\begin{array}{c}-1714.2 \\
(-4.0 \%)\end{array}$ & $\begin{array}{l}+298.8 \\
(+0.7 \%) \\
\end{array}$ & $\begin{array}{c}+2630.9 \\
(+6.2 \%)\end{array}$ & $\begin{array}{c}+11,852.6 \\
(+27.7 \%)\end{array}$ & $\begin{array}{c}-14,142.1 \\
(-33.1 \%) \\
\end{array}$ \\
\hline & Feres (D2) & $\begin{array}{l}-2347.4 \\
(-25.7 \%)\end{array}$ & $\begin{array}{c}-2567.2 \\
(-28.12 \%)\end{array}$ & $\begin{array}{l}-2263.4 \\
(-24.8 \%)\end{array}$ & $\begin{array}{c}0.0 \\
(0.0 \%)\end{array}$ & $\begin{array}{c}-538.9 \\
(-59.0 \%)\end{array}$ \\
\hline & Armenio (D3) & $\begin{array}{l}-723.9 \\
(-5.8 \%)\end{array}$ & $\begin{array}{l}-1977.2 \\
(-15.9 \%)\end{array}$ & $\begin{array}{l}-1844.4 \\
(-14.8 \%)\end{array}$ & $\begin{array}{l}-2787.1 \\
(-22.4 \%) \\
\end{array}$ & $\begin{array}{l}+788.0 \\
(+6.3 \%)\end{array}$ \\
\hline & M.Monastirio (D4) & $\begin{array}{l}-419.9 \\
(-6.0 \%)\end{array}$ & $\begin{array}{c}+737.3 \\
(+10.5 \%)\end{array}$ & $\begin{array}{l}+1365.6 \\
(+19.5 \%)\end{array}$ & $\begin{array}{l}-1793.6 \\
(-25.6 \%)\end{array}$ & $\begin{array}{l}+1537.0 \\
(+21.9 \%)\end{array}$ \\
\hline & Niki (D5) & $\begin{array}{c}+282.9 \\
(+1.8 \%)^{*}\end{array}$ & $\begin{array}{l}-7334.9 \\
(-45.4 \%)\end{array}$ & $\begin{array}{l}-8072.6 \\
(-50.0 \%)\end{array}$ & $\begin{array}{l}-1710.0 \\
(-10.6 \%)\end{array}$ & $\begin{array}{c}-1314.7 \\
(-8.1 \%)\end{array}$ \\
\hline & Sotirio (D6) & $\begin{array}{l}-264.1 \\
(-1.9 \%) \\
\end{array}$ & $\begin{array}{c}-1157.3 \\
(-8.5 \%)\end{array}$ & $\begin{array}{l}-866.8 \\
(-6.3 \%)\end{array}$ & $\begin{array}{l}-2588.6 \\
(-18.9 \%)\end{array}$ & $\begin{array}{l}+1686.4 \\
(+12.3 \%)\end{array}$ \\
\hline & Agnanteri (D7) & $\begin{array}{l}+395.4 \\
(+7.4 \%) \\
\end{array}$ & $\begin{array}{c}+306.9 \\
(+5.71 \%) \\
\end{array}$ & $\begin{array}{l}+498.7 \\
(+9.3 \%) \\
\end{array}$ & $\begin{array}{c}-546.7 \\
(-10.2 \%) \\
\end{array}$ & $\begin{array}{l}+1316.8 \\
(+24.5 \%)\end{array}$ \\
\hline & Kalamaki (D8) & $\begin{array}{c}+92.8 \\
(+0.7 \%)\end{array}$ & $\begin{array}{l}+2403.1 \\
(+18.9 \%)\end{array}$ & $\begin{array}{l}+3606.4 \\
(+28.3 \%)\end{array}$ & $\begin{array}{l}-2427.3 \\
(-19.1 \%)\end{array}$ & $\begin{array}{l}+3772.5 \\
(+29.6 \%)\end{array}$ \\
\hline & Kileler (D9) & $\begin{array}{l}+2946.0 \\
(+20.0 \%)\end{array}$ & $\begin{array}{l}+5891.9 \\
(+40.0 \%)\end{array}$ & $\begin{array}{l}+3413.8 \\
(+23.2 \%)\end{array}$ & $\begin{array}{c}0.0 \\
(0.0 \%)\end{array}$ & $\begin{array}{l}+7366.1 \\
(+50.0 \%)\end{array}$ \\
\hline & Melissa (D10) & $\begin{array}{l}+1753.1 \\
(+20.0 \%)\end{array}$ & $\begin{array}{l}+3399.0 \\
(+38.8 \%)\end{array}$ & $\begin{array}{l}+1531.7 \\
(+17.5 \%)\end{array}$ & $\begin{array}{c}0.0 \\
(0.0 \%)\end{array}$ & $\begin{array}{l}+4382.5 \\
(+50.0 \%)\end{array}$ \\
\hline
\end{tabular}

Note: values in parentheses depict the $\%$ over current water supply

In terms of equilibrium water prices, it is apparent that there are significant differences between the five scenarios, confirming Garrido's (2000) argument that: "equilibrium prices at the district level would be quite different among irrigation districts and that a regional market would provide means to 
reallocate important water quantities". In our case, market prices range from $0.0317 € / \mathrm{m}^{3}$ (Scenario 1 ) up to $0.0430 € / \mathrm{m}^{3}$ (Scenario 3) and, as expected, higher market prices are associated with greater water reductions. Concerning the amount of water traded among the districts, the first conclusion is that there is not a direct link between allocation rule (symmetric or asymmetric) and water rights exchanges. More water is traded under scenarios 3 and 5 , where $9.15 \%$ and $14.60 \%$ of actual water use is going to be reallocated through the inter-district allocation system. Some areas, like Kileler (D9) and Melissa (D10) will act as water buyers or - in some extreme cases - as non-participants in the market (i.e. $b_{i} \geq 0$ ) in all water supply scenarios. On the other hand, the district of Feres (D2) is very likely to constitute a water seller $\left(b_{i} \leq 0\right)$ no-matter what initial allocation rule will be followed. All the other districts are either buyers or sellers, depending on their initial water allotment. Figures 2 and 3 present the potential spatial aspects of water trading for symmetric (Scenarios $1 \& 3$ ) and asymmetric (Scenarios 4 \& 5) water cuts.

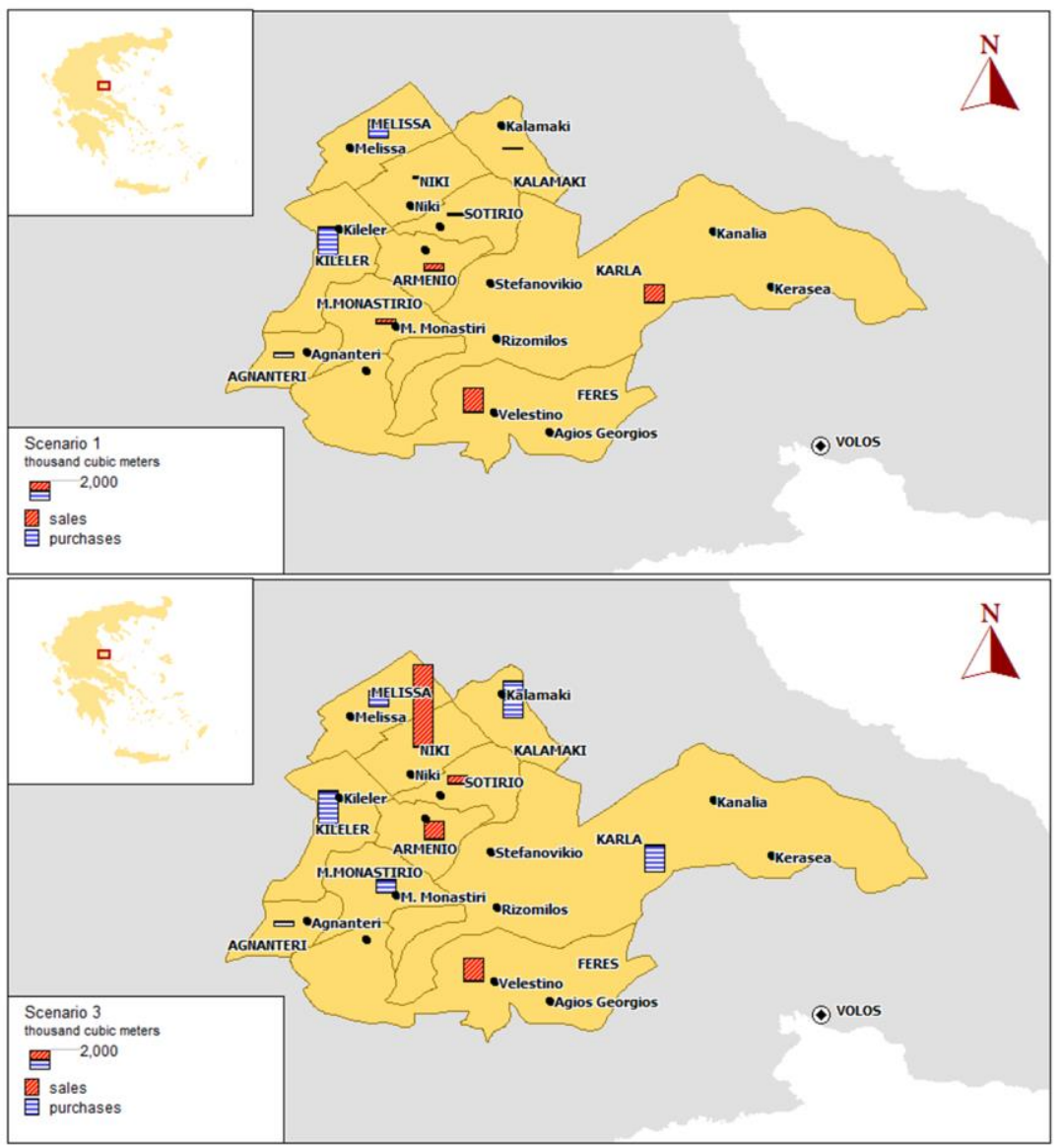

Figure 2. Water transactions under symmetric water reduction scenarios

\section{Discussion and conclusions}

The implication of a market-based system was examined in an intensively irrigated area, such as Lake Karla basin, where irrigation water is currently treated as a free-access resource. However, as state by Skurray et al. (2012): "the larger the management area, the greater the theoretical potential for the concentration of impacts due to the spatial redistribution under trading". For this reason we limit our analysis at the sub-basin-level. The market-based allocation system was actually simulated from a social planner's perspective, trying to maximize aggregate economic benefits under various water supply scenarios. The policy scenario examines the potential gains from an institutional change in the study area that will develop participatory approaches to water allocation and water trading decisions among various districts. On this account it is assumed that all irrigators in each district will act through local 
Water Users Associations (WUAs). The reason for using this approach is that it will provide both financial autonomy and confidence to farmers. Besides, as noted by Calatrava and Garrido (2005): "as farmers' confidence in trading system increases, the efficiency gains that can eventually be achieved include not only better water allocation, but also more efficient tactical responses to face supply uncertainty".

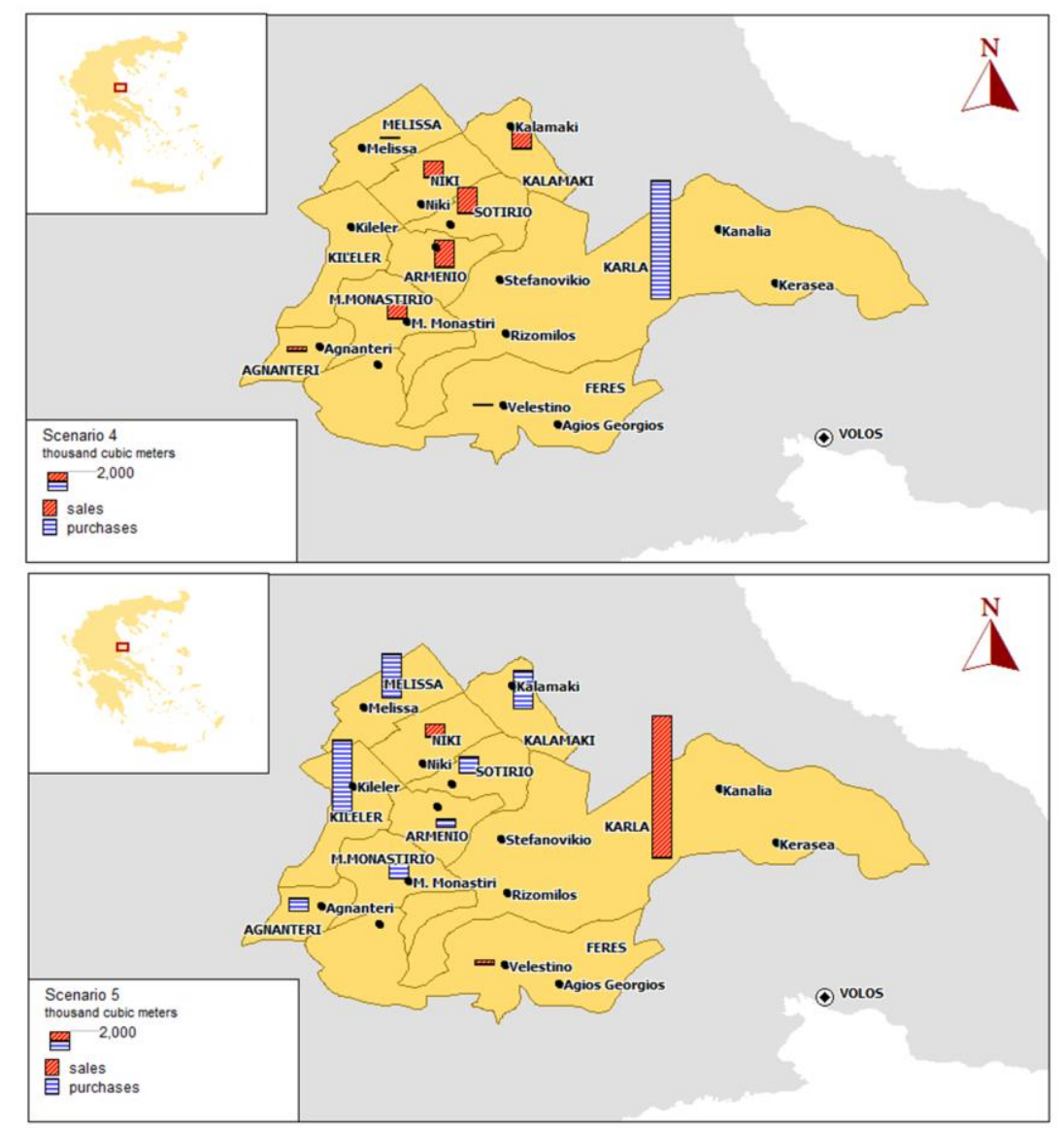

Figure 3. Water transactions under priority based (asymmetric) allocation scenarios

Optimization techniques, at the district level, were first used in order to derive the demand functions for irrigation water. Local agricultural decision-making is supposed to maximize the benefit functions under a set of land and water availability constraints. In the next step of analysis, a market-based allocation mechanism was simulated, according to which, WUAs would be able to trade water-rights in future cases of water scarcity. Several scenarios were formulated, representing different levels of water reductions and a non-linear maximization model was applied. The overall objective of this model was to maximize, in a Pareto way, the aggregated economic benefits through trading of WUAs' water rights. Hence, districts that are interested in purchasing additional volumes of water would buy these volumes from districts that are willing to sale water rights, at a price higher than their current shadow price of water. Within the international literature, it is not uncommon to find similar models that introduce market equilibrium conditions to assure that the shadow prices for water are equal among users or districts (Garrido, 2000; Weinberg et al., 1993).

According to the results of the allocation model, significant volumes of water would be traded under various deficit scenarios, mainly due to the spatial heterogeneity in water use and availability. Concerning the selected policy scenarios, market prices range from $0.032 € / \mathrm{m}^{3}$ to $0.043 € / \mathrm{m}^{3}$, where higher prices are associated, as expected with greater water reductions. This result is in agreement with the findings of Qureshi et al. (2009), indicating a willingness of farmers to pay higher prices for more secure water. Useful conclusions were also drawn concerning the amount of water traded among the districts. Namely, it was found that there is not a direct link between allocation rule (symmetric or 
asymmetric) and total water exchanges. Nevertheless, the potential trading activity (strategy) of each district (WUA) seems to depend heavily on its initial water allotment.

The final conclusion of the present work is that a market-based allocation system, supervised at the basin-level can be very beneficiary for irrigation districts in arid and semi-arid countries under future scenarios of water scarcity (e.g. in designing adaptation measures to improve water institutional resilience in future climate change conditions). Similar conclusions were also drawn from a recent study of Gohar and Ward (2010), who found significant benefits from allowing intra-regional trade in the Nile Basin in Egypt.

\section{References}

Albiac J., Playan E. and Martinez Y. (2007), Instruments for water quantity and quality management in the agriculture of Aragon, International Journal of Water Resources Development, 23(1), 147-164.

Berbel J., Calatrava J. and Garrido A. (2007), Water pricing and irrigation: A review of the European experience, in F. Molle and J. Berkoff (eds), Irrigation Water Pricing Policy: The Gap Between Theory and Practice, CABI, IWMI, Wallingford, UK, 295-327.

Çakmak B., Beyribey M. and Kodal S. (2004), Irrigation water pricing in water user associations, Turkey, Water Resources Development, 20(1), 113-124.

Calatrava J. and Garrido A. (2005), Modelling water markets under uncertain water supply, European review of agricultural economics, 32(2), 119-142.

Cornish G., Bosworth B., Perry C. and Burke J. (2004), Water charging in irrigated agriculture: an analysis of international experience, FAO Waters Reports, 28. FAO, Rome, Italy

Doorenbos J. and Kassam A.H. (1979), Yield Response to Water, FAO Irrigation and Drainage Paper, No.33, Rome, Italy.

Dudu H. and Chumi S. (2008), Economics of irrigation water management: a literature survey with focus on partial and general equilibrium models, Policy research working paper, The World Bank, Washington DC, p. 65.

Easter K.W. (1996), Market approaches to water allocation: What have we learned? Paper presented at 5th Joint Conf. on Agriculture, Food and the Environment, Padova, Italy. June 17-18.

Easter K.W. and Hearne R. (1995), Water markets and decentralized water resources management: International problems and opportunities, Water Resources Bulletin, 31(1), 9-20.

Easter K.W. and Liu Y. (2007), Who pays for irrigation: cost recovery and water pricing?, Water Policy, 9, 285-303

European Commission (2000), Directive 2000/60/EC of the European Parliament and of the Council, Establishing a framework for the community action in the field of water policy. Official Journal of the European Community, L327, 22/12/2000, p.1

Garrido A. (2000), A mathematical programming model applied to the study of water markets within the Spanish agricultural sector, Annals of Operations Research, 94, 105-123.

Getches D.H. (1993), Essays from Askhabad, to Wellton-Mohawk, to Los Angeles. The drought in water policy, University of Colorado Law Review, 64, 523-553.

Gohar A.A. and Ward F.A. (2010), Gains from expanded irrigation water trading in Egypt: an integrated basin approach, Ecological Economics, 69, 2535-2548.

Griffin R.C. 2006. Water Resource Economics: The Analysis of Scarcity, Policies and Projects, Cambridge, MA: MIT Press.

Hamdy A. and Lacirignola C. (1997), Water users' associations and sustainability of irrigation systems, Mediterranean, 3, pp. 4-9

Iglesias E. and Blanco M. (2008), New directions in water resources management: The role of water pricing policies, Water Resources Research, 44(6).

Kastens B. and Newig J. (2008), Will participation foster the successful implementation of the water framework directive? The case of agricultural groundwater protection in northwest Germany, Local Environment, 13, 27-41. 
Keenan S.P., Krannich R.S. and Walker M.S. (1999), Public perceptions of water transfers and markets: describing differences in water use communities, Society and Natural Resources: An International Journal, 12 (4), 279-292.

Latinopoulos D. (2005), Derivation of irrigation water demand functions through linear and non-linear optimization models: application to an intensively irrigated area in northern Greece, Water Science and Technology: Water Supply, 5(6), 75-84.

Latinopoulos D. (2008), Estimating the potential impacts of irrigation water pricing using multicriteria decision making modelling. An application to Northern Greece, Water resources management, 22(12), 1761-1782.

Latinopoulos D. and Sartzetakis E. (2011), Optimal exploitation of groundwater and the potential for a tradable permit system in irrigated agriculture, European Association of Environmental and Resource Economists (EAERE), $18^{\text {th }}$ Annual Conference, 29 June -2 July 2011, Rome, Italy.

Loukas A., Mylopoulos N. and Vasiliades L. (2007), A Modeling System for the Evaluation of water resources management strategies in Thessaly, Greece, Water Resources Management, 21, 1673-1702.

Loukas A., Mylopoulos N., Kokkinos K., Sidiropoulos P., Vasiliades L. and Liakopoulos A. (2008), The effect of spatial discretization in integrated modeling of surface and groundwater hydrology through OpenMI. Paper presented at the International Interdisciplinary Conference on Predictions for Hydrology, Ecology and Water Resources Management - Using Data and Models to Benefit Society, Prague, Czech Republic, 2008.

Munaretto S. (2003), Irrigation governance in Mediterranean regions: comparing case studies in Italy, Spain, Morocco, Lebanon, Greece. SIRRIMED ( $7^{\text {th }}$ Framework Programme), Project deliverable 6.3, Institute for environmental studies, VU University, Amsterdam (17/12/2013).

Panagopoulos Y., Makropoulos C., Kossida M. and Mimikou M. (2013), Optimal implementation of irrigation practices: cost-effective desertification action plan for the Pinios Basin, Journal of Water Resources Planning and Management, http://dx.doi.org/10.1061/(ASCE)WR.1943-5452.0000428.

Organization for Economic Cooperation and Development (OECD) (2001), Methods and results: Executive summary, in Environmental Indicators for Agriculture, vol. 3, Paris.

Ortega J.F., de Juan J.A. and Tarjuelo J.M. (2004), Evaluation of the water cost effect on water resource management: Application to typical crops in a semiarid region, Agricultural Water Management, 66(2), 124-144.

Qureshi M.E., Shi T., Qureshi S.E. and Proctor W. (2009), Removing barriers to facilitate efficient water markets in the Murray-Darling Basin of Australia, Agricultural Water Management, 96, 1641-1651.

Saleth R.M. and Dinar A. (1999), Water challenge and institutional response: A cross-country perspective, Research Policy Working Paper No2161, The World Bank, Washington, D.C.

Skurray J.H., Roberts E.J. and Pannell D.J. (2012), Hydrological challenges to groundwater trading: Lessons from south-west Western Australia, Journal of Hydrology, 412-413, 256-268.

Schrage L. (1999), Optimization modeling with LINGO (5th edition), Chicago, IL: LINDO Systems Inc.

Smith M. (1992), CROPWAT - A computer program for irrigation planning and management, FAO Irrigation and Drainage Paper, No.46, Rome, Italy.

WATECO (2002). Economics and the Environment - the Implementation Challenge of the Water Framework Directive. Common Implementation Strategy for the Water Framework Directive, Guidance Document No. 1, produced by Working Group 2.6. Luxembourg.

Weinberg M., Kling C.L. and Wilen J.E. (1993), Water markets and water quality, American Journal of Agricultural Economics, 75(2), 278-291.

WFD Public participation working group (2002), Guidance on public participation in relation to the WFD: Active involvement, consultation and public participation, December 2002.

Zilberman D. and Schoengold K. (2005), The use of pricing and markets for water allocation. Canadian Water Resources Journal, 30, 47-54. 